\title{
The Disputed Bounds of Muslim Warfare
}

\section{Onder Bakircioglu*}

\begin{abstract}
The justificatory grounds of Muslim war have long been subject to various interpretive analyses, which have taken customary, literalist, revivalist or reformist modalities of hermeneutics. Although scholars of jihad stand on a broader intellectual terrain, one may identify two major streams of thought: the 'moderate' and 'radical' schools. The principal bone of contention between these schools appertains to the question of whether a legitimate jihad is confined to self-defensive measures alone, or whether it may transcend such measures and be fought in furtherance of political ambitions. This article critically analyses such doctrinal views on Islamic jus ad bellum, arguing that the mainstream depiction of jihad is largely mono-dimensional that fails to capture the overall phenomenon within its contingent framework.
\end{abstract}

\section{Introduction}

The justificatory bases of Muslim war have long been subject to heated disagreement and debate. Since the sources of Islam are non-linear in format and esoteric in content, students of Islam are divided on legitimate causes of jihad, with Muslim scholars generally offering mutually exclusive theories. While scholars of jihad stand on a broader hermeneutical terrain (ranging from orthodox to reformist, literalist to progressive, revivalist to secular modalities of thinking), it is possible to identify two major conflicting strands of thoughts: the so-called 'moderate' and 'radical' schools. These scholarly streams lack a homogenous voice, but one may discern some central themes that they commonly address.

This article will neither seek to impose a forced unity of voice on the schools examined, nor will it dedicate much space to marginal minority views in each of these intellectual edifices. Rather, the aim is to have a focused, critical discussion of the dominant Sunni positions defining the key characteristics of Muslim jus ad bellum. The principal bone of contention between the moderates and radicals appertains to the question of whether legitimate Muslim warfare is confined to selfdefence, or whether it may also be fought in furtherance of such ambitions as expanding Muslim sphere of influence, or taking punitive action against idolatry, immorality and apostasy. Moderate scholars, in brief, envision that military jihad is only an instrument of self-defence to be invoked when feasible efforts to peacefully resolve a conflict fail. Radicals, on the other hand, generally view warlike jihad both as a tool of self-defence and of effectuating socio-political change.

\footnotetext{
* Associate Professor, Leicester Law School. Email: onder.bakircioglu@le.ac.uk. The author wishes to thank the anonymous reviewers for their helpful comments and suggestions.
} 
Over the past decades the latter view has gained notable traction, which is evinced by the growing scale of politico-religiously motivated violence. In their quests to thwart Western influence over the Muslim world and to replace all 'un-Islamic' regimes with theocracies intent on eradicating 'immoral' practices, radicals place heavy emphasis on bellicose jihad. Militant-salafi-inspired ${ }^{1}$ movements of al-Qaeda and the Islamic State of Iraq and Syria (ISIS), for instance, engage in such belligerent jihadi exegeses. Such Islamists are purportedly committed to obliterate secular systems and purge the world of 'ungodly' people. ${ }^{2}$ What is more, fundamentalists have of late widened the sweep of their adversaries. Apart from the customary taxonomy of enemies (e.g. infidels, blasphemers or heretics) ISIS has come to employ the concept of 'apostate,' which amorphously subsumes Shias, Yezidis, Sufis, and, worse, all secular-minded Muslims, and those that denounce ISIS' obscurantist ideas. Defying the Islamic rule against internecine fighting among Muslims, ${ }^{3}$ ISIS peculiarly maintains that those who resist its rule are simply apostates or rebels who must be put to the sword. ${ }^{4}$

Crucially, unlike the fundamentalist non-state actors, Muslim-majority States do not, in principle, turn to religious paradigms to buttress their just war claims. ${ }^{5}$ Instead, they usually attempt to legitimate their combative conduct by reference to the United Nations Charter, which, in essence, prohibits armed force except for self-defence, or with the authority of the UN Security Council. ${ }^{6}$ While some Muslim-majority States occasionally draw on the narrative of jihad to rally popular support, at the international level they make an effort to provide legal grounds for their conduct. ${ }^{7}$ Fundamentalist groups, on the other hand, invoke religious conceptualisations for their bellicose behaviour, spurning the authority of international law and its secular modes of adjudication. ${ }^{8}$ With its spurious claims of caliphate and statehood, ISIS, in this context, alleges to be besieged by the forces of 'unbelief,' and thus arrogates itself the right of self-defence against ill-defined

\footnotetext{
${ }^{1}$ Salafi-jihadi movements advocate a return to the basics of Islam as regulated by the Quran and practiced by early Muslims (salafis). See O Roy, L'Asie Centrale Contemporaine $\left(4^{\text {th }}\right.$ edn, Presses Universitaires de France 2010) 64-66. A Saeed, 'Salafiya, Modernism, and Revival,' in: JL Esposito; EE Shahin (eds.) The Oxford Handbook of Islam and Politics (OUP 2013) 27

${ }^{2}$ OB Laden, 'Moderate Islam is a Prostration to the West,' in: R Ibrahim (ed.) The al-Qaeda Reader (Broadway Books 2007) 50-51.

${ }^{3}$ See G Kepel, Fitna: Guerre au cour de l'islam (Gallimard 2004) 15.

${ }^{4}$ See W McCants, The ISIS Apocalypse: The History, Strategy, and Doomsday Vision of the Islamic State (St. Martin's Press 2015) 34.

${ }^{5} \mathrm{~J}$ Rehman, Islamic State Practices, International Law and the Threat from Terrorism: A Critique of the 'Clash of Civilisations' in the New World Order (Hart Publishing 2005) 53ff.

${ }^{6} \mathrm{O}$ Bakircioglu, Self-Defence in International and Criminal Law: The doctrine of Imminence (Routedge 2011), 134-187.

${ }^{7}$ See G Kepel, Jihad: The Trail of Political Islam (I.B. Tauris 2006) 205.

${ }^{8}$ See C Bunzel, 'From Paper State to Caliphate: The Ideology of the Islamic State' The Brookings Project on U.S. Relations with the Islamic World, Analysis Paper, March 2015, 29.
} 
threats, calling on all to desist from countering its 'righteous' overtures. ${ }^{9}$ Since professions of self-righteousness in war hardly lend themselves to dispassionate evaluations, it is imperative to scrutinise the normative postulates and key attributes of just war claims made by Muslim pundits and fundamentalist actors. This will allow us to appraise whether their just war claims conforms to the normative standards of Muslim just war tradition.

This article will subject the main intellectual stands on Islamic jus ad bellum to critical scrutiny. It will, in essence, expose that the mainstream depiction of the doctrine of jihad is restricted or mono-dimensional, which exclusively highlights either peaceful or warlike aspects thereof; thus failing to capture the overall phenomenon within its relativistic and contingent framework. The article will, in this context, unravel that the modern discourse on jihad mainly generates mutually incompatible verdicts as to whether or not jihad comprehends offensive wars. It will further show that partisan references to Muslim sources has contributed little to the emergence of a convincing metanarrative on the defining features of jihad.

Such an analysis will be coupled with the argument that those who draw antithetical distinctions between defensive and offensive forms of jihad often single out a select class of verses, traditions (Sunna) and doctrines to underpin their monolithic standpoints at the expense of a more nuanced portrayal of Muslim just war, which will be shown to have never possessed uncontested contours. The central thesis of the article will be that the disputed meaning and varied applications of jihad have largely been dependent on the socio-political circumstances of each historical context which generated divergent hermeneutics. It will accordingly be argued that any exegetical attempt at drawing a clear-cut delineation between permissible and impermissible forms of jihad must consider the overall object and purpose of Islam along with the practical dynamics which have redefined the bounds of Muslim warfare. This article will first subject the central ideas advanced by moderate and radical streams on the doctrine of jihad to critical scrutiny. It will then proceed with the presentation of a more nuanced and relativistic depiction of military jihad.

\section{The Moderate Reading of Jihad}

The tapestry of the Quran and the Sunna (i.e. the primary sources of Sharia) concerning justified lethal force is mainly non-linear in structure and content. ${ }^{10}$ When read literally, therefore, whilst some verses and traditions denounce aggression, enjoining Muslims to fight only in self-defence,

\footnotetext{
${ }^{9}$ See AV Engeland, 'Statehood, Proto States and International Law: New Challenges, Looking at the Case of ISIS' in: J Crawford et al (eds), The International Legal Order: Current Needs and Possible Responses (Brill 2017) $75 \mathrm{ff}$.

${ }^{10}$ See R Firestone, Jihad: The Origin of Holy War in Islam (OUP 1999) 47.
} 
others seem to give grounds for the use of force to subdue unbelievers or to augment the politicogeographical reach of Islam. Strikingly, a substantial measure of such verses and traditions may be used to underpin these incongruous positions, ${ }^{11}$ so much so that by capitalising on handpicked injunctions, some scholars deduce progressive ideas embracing a peaceful approach to resolving conflicts, and others infer warlike postulations to legitimate Islamist supremacy or aggression. ${ }^{12}$

In this controversy, the moderate stance rejects the idea of offensive jihad, taking issue with the assertion that jihad is more about a relentless struggle to eradicate the agents of immorality, or forcefully establishing a rightful Islamic State under the leadership of a universal caliphate. ${ }^{13}$ The origins of moderate thinking are rooted in the long-held reformist aspiration to overcome the socio-political impasse in which most Muslim-majority societies have found themselves since the decline of Islam as an intellectual and political force. Promoting a progressivist form of faith, moderates generally posit that 'revealed' knowledge (the Quran and Sunna) does not necessarily clash with critical thinking (ijtihad), ${ }^{14}$ and that progress is possible by discarding warmongering policies and rereading Islamic sources in accordance with the spirit of times. ${ }^{15}$ Unlike radicals, moderates dismiss violence as a means of Muslim revival. Indeed, while opposed to all forms of colonial enterprise over the Muslim world and the corrupt policies of Muslim rulers, moderates reject military jihad to effectuate change. To reform-minded moderates, while Muslim dynamism has become stultified by the traditionalist orthodoxy, it may be reinvigorated through free debate, rigorous scholarship and tolerance. ${ }^{16}$

As regards the true meaning of jihad, moderate scholars challenge the parochial understanding, or crude translation of the term jihad as 'holy war.' ${ }^{17}$ This would indeed be misleading, because it conceals the intricacies of the doctrine by reducing it to downright bellicosity. Jihad, moderates correctly stress, literally means 'endeavouring,' 'exerting' or 'struggling' in the way of God. ${ }^{18}$

\footnotetext{
${ }^{11}$ See, e.g., Q. 2:256; Q. 2:190; Q. 9:13; cf. Q. 9:5; Q. 9:29; Q. 9:123.

12 See Kepel (n 3) 16; NJ Delong-Bas, 'Islam and Power in Saudi Arabia,' in: Esposito (n 1) 411, 421.

${ }^{13}$ See S Jackson, 'Jihad and the Modern World' in: JJ Donohue; JL Esposito (eds.), Islam in Transition: Muslim Perspectives ( $2^{\text {nd }}$ edn, OUP 2007) 408; P. Bannier, L'etat islamique et le bouleversement de l'ordre régional (Verso 2015).

${ }^{14}$ JL Esposito, 'Trailblazers of the Islamic Resurgence' in: Y Haddad et al (eds.), The Contemporary Islamic Revival: A Critical Survey and Bibliography (Greenwood Publishing 1991) 37, 53.

${ }^{15}$ See F Rahman, Islam \& Modernity: Transformation of an Intellectual Tradition (The University of Chicago Press 1982); T Ramadan, Radical Reform: Islamic Ethics and Liberation (OUP 2009); AA Na'im, 'Islam and International Law: Toward a Positive Mutual Engagement to Realise Shared Ideals' (2004) 98 ASIL 159; MH Kamali, Principles of Islamic Jurisprudence (The Islamic Texts Society 1989).

${ }^{16}$ See O Roy, Secularism Confronts Islam (Columbia University Press, 2007) 45.

${ }^{17}$ See MA Haleem Understanding the Qur'an: Themes and Style (IB Tauris 2011) 62.

${ }^{18} \mathrm{H}$ Zawati, Is Jihad a Just War: War, Peace, and Human Rights under Islamic and Public International Law (The Edwin Mellen Press 2001) 13.
} 
In fact, despite widespread reference to jihad, military force is referred to under different headings. The Quran, for example, makes occasional reference to harb, which is a generic concept for war, and qital, which mainly connotes military force undertaken in the path of God. ${ }^{19}$ Jihad, however, is a more comprehensive concept, as moderates stress. While in its narrow military sense it may entail belligerent conduct, its broader meaning encompasses such righteous deeds as striving for justice, proselytising Islam peacefully, seeking wisdom and avoiding sins. Moderates hence posit that armed force represents only one aspect of jihad, for the concept connotes not merely military measures (albeit defensive), but also debate and persuasion through dialogue and other unwarlike methods of exerting oneself for God. ${ }^{20}$ For moderates, peaceful modalities of jihad are mainly encapsulated in the following Quranic dicta: 'Overlook (faults) with gracious forgiveness' (Q. 15:85); 'Turn away from them [the oppressors]' (Q. 43:89); 'Repel (evil) with what is better' (Q. 41:34); 'To you be your way, and to me mine' (Q. 109:6); and there is 'No compulsion in Islam' (Q. 2:256). It will be seen that these verses stand in stark contrast to the bellicose 'sword' verses. ${ }^{21}$

Moderates further highlight such peaceful aspects of jihad, which demand believers to propagate their convictions verbally (i.e. 'jihad by the tongue'), to perform pious deeds (i.e. 'jihad by the hand'), and to engage in spiritual struggle against one's depraved temptations (nafs) (i.e. 'jihad by the heart'). ${ }^{22}$ Particular emphasis is placed on fighting the nafs as a way of purging the soul of 'sins.' Though this is likely to cultivate spiritual growth, which might in turn spur benevolent deeds, it is said to be more taxing; arguably because inner foes can neither be directly confronted, or be everlastingly defeated. It is probably for this reason that this inward-looking jihad is claimed to constitute the 'greater jihad' (jihad al-akbar). Textual support for the superiority of the 'greater jihad' comes from an oft-cited tradition, wherein the Prophet had reportedly told his companions: 'We return from the lesser jihad [Tabuk battle of 630] to the greater jihad [spiritual battle]. ${ }^{, 23}$

The impact of this tradition (whose reliability is questioned due to its absence from authoritative compilations $)^{24}$ has been so prominent that ever since its circulation moderates have asserted that

\footnotetext{
${ }^{19}$ See Firestone (n 10) 18.

${ }^{20}$ M Khadduri, War and Peace in the Law of Islam (John Hopkins Press 1955) 55-56; MC Bassiouni, The Shari'a and Islamic Criminal Justice in Time of War and Peace (CUP 2014).

${ }^{21}$ See, e.g., Q. 2:51; Q. 5:51; Q. 9:29.

${ }^{22}$ See M Mir, 'The Qur'an and the Word of God' in: VJ Cornell (ed.), Voices of Islam, (Vol. I, Praeger 2007) $206 \mathrm{ff}$.

${ }^{23}$ This tradition is found in al-Ghazali (d. 1111) in 'ulum al-din, translated by K Nakamura as Ghazali on Prayer (University of Tokyo 1973) 167.

${ }^{24}$ Credible hadith collectors include Sahih al-Bukhari, Sahih Muslim, Ahmad ibn Hanbal, Sahih al-Sijistani, Abu Isa al-Tirmidhi, and al-Nasai. See MZ Siddiqi, Hadith Literature: Its Origin, Development \& Special Features (The Islamic Texts Society 2008) 125-127.
} 
self-improvement is much more rewarding than fighting wars. ${ }^{25}$ This is not the only tradition of disputed authenticity which brings spiritual growth to the fore. Some parallel traditions define a mujtahid (one engaged in jihad) as one 'who wages a struggle against himself,' ${ }^{26}$ or 'who makes jihad against his nafs. ${ }^{27}$ While not in canonical collections, these traditions bear significance, as they not only chime with the peaceful tenets of Islam, but also drive home the point that constant endeavour to attain peace forms the cornerstone of jihad.

Clearly, whilst the aspiration to secure peace is part of the Muslim war tradition, ${ }^{28}$ Islam is not a pacifistic religion. Islam recognises self-defence as a natural entitlement, which, as moderates would probably concur, may prove vital to prevent Muslims from being disadvantaged vis-à-vis hostile forces. Moderates, however, argue that defensive military jihad is an exceptional measure, which is confined to the narrow object of frustrating unprovoked aggression. ${ }^{29}$ Relatedly, Muslim force to fend off aggression must be strictly necessary, and proportionate to the threat faced. ${ }^{30}$ There is, in fact, scriptural support to substantiate these points. Q. 2:190, for example, highlights the need to invoke only proportionate measures: 'Fight in the cause of Allah those who fight you, but do not transgress limits.' The following injunction restricts the breath of defensive force: 'And if one has retaliated to no greater extent than the injury he received, and is again set upon inordinately, God will help him'(Q. 22:60). Also the idea that one should not use force more than what is needed is embedded here: 'Fight them on until there is no more tumult or oppression, and there prevail justice and faith in God altogether and everywhere' (Q. 8:39).

Such a non-belligerent, defensive reading of jihad surely dovetails with the idealised construction of Islam as a religion of peace. Yet if self-defensive wars are only aimed at thwarting unprovoked assaults, then Muslims may never initiate wars to aggrandise their politico-economic influence. It is at this point not critical to question whether Islam is devoid of imperial ambitions. Suffice to note here that defensive warfare against bellicose encroachments are not anathema to Islam; yet, as moderates emphasise, such defensive measures are qualified by the notions of distinction,

\footnotetext{
${ }^{25}$ See J Renard, 'Al-Jihad Al-Akbar: Notes on a Theme in Islamic Spirituality’ (1988) 78 The Muslim World 225, 227; also see L Massignon, La guerre sainte suprême de l'islam arabe (Fata Morgana, 1998).

${ }^{26}$ Reported by Musnad Ahmad (6, 20-22); also see MH Kamali, 'Jihad and the Interpretation of the Qur'an: Contextualising Islamic Tradition' in: MC Bassiouni; A Guellali (eds.), Jihad and its Challenges to International and Domestic Law (Hague Academic Press 2010) 39, 44.

${ }^{27}$ Reported by Ibn Hibban $(1624,2519)$.

${ }^{28}$ See Q. 49:13.

${ }^{29}$ See J Kelsay, 'Religion, Morality, and the Governance of War: The Case of Classical Islam' (1990) 18 Journal of Religious Ethics 123, 123; JB Elshtain, 'Just War and Humanitarian Intervention' (2001) 17 AUILR 1, 5-6.

${ }^{30}$ See IA Qazwini, 'Just War: An Islamic Perspective’ (2004) 9 Nexus 79, 83.
} 
necessity and proportionality. ${ }^{31}$ In other words, defensive fighting is legitimate when it is indeed imperative, and not in excess of what is reasonable and humane.

\section{A. A Closer Look at Moderate Thinking}

It should now be clear that it is in accord with the afore-mentioned trend that most contemporary Muslim scholars have come to accentuate the unwarlike aspects of jihad. It is worth noting that the roots of this thinking are embedded in the early twentieth-century Muslim reformism, which, among others, rejected such militant approaches that glorified martial virtues, considering war as a quotidian tool for resolving differences. ${ }^{32}$ These reformers were concerned to promote the idea that warlike jihad is permissible in self-defence alone. It is from this vantage point that prominent twentieth-century liberals, including Muhammad Abduh (d. 1905) and Rashid Rida (d. 1935), argued that peaceful coexistence between Muslim and non-Muslim entities has constituted the normative state of affairs. ${ }^{33}$ Likewise, Mahmud Shaltut (d. 1963), the reformist rector of al-Azhar University, maintained that jihad was purely defensive, for the Quran categorically 'prohibits the provocation of hostility, [a point which] is reinforced by God's repugnance to ... those who provoke hostility. ${ }^{34}$

Echoing kindred views, contemporary thinker, Sheikh al-Zuhili (d. 2015), sought to construct a drawbridge between religious and secular thinking on Muslim warfare by thrusting humanitarian sides of jihad forward. To Al-Zuhili, 'warfare is only for defence, to prevent injustice and fend off aggression. ${ }^{35}$ Dismissing the idea that historical Islam had imperial colours, he argued that Muslim wars of the classical period had been fought to ensure the survival of Muslims and raise 'the banner of freedom among all nations.' ${ }^{36}$ Evidently, however, fighting to secure 'freedom' or 'divine supremacy' does not always mean that wars are confined to self-defence. Such a construal of warfare is too expansive as to bring any clarity to the defining characteristics of jihad. Also, an inexorable hurdle in assessing the 'justness' of a war is that any evaluation of the conflict from the partisan prism of the warring parties would in all likelihood lend itself to two incompatible views. What looks like an open-and-shut case of self-defence to one party might appear as sheer aggression to the other.

\footnotetext{
${ }^{31}$ See NA Shah, Self-Defence in Islamic and International Law: Assessing Al-Qaeda and the Invasion of Iraq (Palgrave 2008) 17ff.

32 See NA Zayd, Reformation of Islamic Thought: A Critical Historical Analysis (Amsterdam University Press 2006) 37-78.

${ }^{33}$ R Peters, Jihad in Classical and Modern Islam (Markus Wiener Publishers 1996) 6.

${ }^{34}$ Mahmud Shaltut, 'The Koran and Fighting,' R. Peters (trans.), ibid. 64-74.

${ }^{35}$ SA Zuhili, 'Islam and International Law' (2005) 87 IRRC 269, 273.

36 Ibid. 271.
} 
Another contemporary scholar reducing the military facets of jihad to self-defensive measures is Bassiouni (d. 2017). He writes that most Quranic exhortations call on Muslims to be steadfast and sacrificing in their efforts, and to engage in peaceful propagations of the faith. He adds that although later (Medinan) verses on jihad have a less conciliatory tone than the earlier ones, such subsequent injunctions are still conceived in defensive terms. ${ }^{37}$ Again, by this reading, the most salient feature of jihad is the inception of aggression. Some other contemporary commentators ${ }^{38}$ advance a correlative postulate that Islam defies the sword as a means of settling disputes. At the heart of such analyses, however, lies supportive peaceable verses and traditions, and not the more bellicose ones of the Medinan phase. ${ }^{39}$

Certainly, the opposition of the moderate philosophy to offensive jihad is not only predicated on select verses and traditions. Reference is further made to the overall ethical framework of Islam that places significant stress on such notions as justice, peace, equity, compassion and tolerance. ${ }^{40}$ Kamali, in this context, comments that Islam has always had a tolerant and civilising vision that constrains injustice and wanton violence. ${ }^{41}$ Islamic commitment to peace, he adds, is borne out by its 'wealth of teachings on human fraternity, compassion, justice, beneficence ..., avoidance of harm to others, and ... resistance to provocation. ${ }^{42}$ By heavily accentuating such messages of inclusivity, peace and tolerance, moderates hence defend the notion that all offensive wars are anathema to God, and that lethal force should be a last resort against illicit aggression. Under this narrative, Muslims must normatively settle their differences amicably, ${ }^{43}$ and comport themselves with restraint in cases of unavoidable conflicts. ${ }^{44}$ Moderates, then, promote the preponderance of peace over war, forgiveness over avenge, compassion over cruelty, and love over hate.

The presumed moral supremacy of peace over crude belligerency chimes with the oft-repeated postulation that Islam is a religion of peace and tolerance. This idea is usually bolstered with the

\footnotetext{
${ }^{37}$ Bassiouni (n 20) 207.

${ }^{38}$ See AA An-Na'im, Islam and the Secular State: Negotiating the Future of Shari'a (HUP 2008); Rehman (n 5); Zawati (n 18); Asghar Ali Engineer, 'On Developing Theology of Peace in Islam' (Sterling Publishers 2005) 5-7; Shah (n 31).

${ }^{39}$ Likewise, the advocates of moderate discourse "do not [generally] refer to the classical doctrines of jihad and prefer to cite the authoritative primary sources, [the] Quran and Sunna.' A Guellali, 'Understanding the Discourses on Jihad in Islam' in: Bassiouni (n 26) 59, 75.

${ }^{40}$ See An-Na'im (n 38) 111ff; Rehman (n 5) 51ff; Ramadan (n 40) 207-232; JL Esposito, The Future of Islam (OUP 2010) 86ff.

${ }^{41}$ MH Kamali, 'Islam and Civilizational Renewal' 2016 (7) IAIS 157, 160.

${ }^{42}$ Ibid. 159.

${ }^{43}$ See Q. 42:40; Q. 4:114.

${ }^{44}$ See Zawati (n 18); also see N Mohammad, 'The Doctrine of Jihad: An Introduction' (1985) 3 Journal of Law and Religion 381; HA Haleem et al (eds.), The Crescent and the Cross (Macmillan Press 1998).
} 
celebrated verse of 'non-compulsion' which reads: 'Let there be no compulsion in religion: truth stands out clear from error: whoever rejects evil and believes in Allah hath grasped the most trustworthy handhold that never breaks' (Q. 2:256). To moderates, this verse constitutes one of the mightiest pillars of Islam, a scriptural buttress for the idea that Islam is a religion of broadmindedness and conciliation. The verse is thus argued to rebut the sweeping assertion that Islam has been a religion of the sword spread through conversations at blade point. ${ }^{45}$ Moderates could surely invoke another verse of arguably equal strength, which reads: 'If it had been the Lord's will, they would all have believed. All who are on earth, wilt thou then compel mankind, against their will, to believe?' (Q. 10:99). This verse patently rejects the idea of forceful conversions, as forced belief does not stem from the exercise of free will, by which an action might be subjected to praise or blame.

If, however, enforced conversations and suppression of contrarian religious ideas do not square with the core tenets of Islam, then Islamic military conquests would have to be accounted for. Clearly, Muslim polities had over time come to dominate a wide array of territories not by means of defensive engagements, but mainly through offensive wars aimed at establishing the political ascendancy of Islam. ${ }^{46}$ This phenomenon might be explained away by moderates as being part of the temporal practices of expansionist potentates who ostensibly hid their worldly ambitious behind the façade of Islam. Viewed thus, the spread of Muslim dominion through lethal measures would probably be perceived as a practical upshot, rather than the normative state of affairs. But from a theoretical and historical perspective, such reasoning cannot stand close scrutiny. Indeed, if warlike measures could not exceed the confines of defending Islam, then the vast expansion of the Muslim realm over the course of history should convincingly be explained. Recall that early Muslim expeditions into the Byzantine and Persian territories, which resulted in the conquest of Byzantium's southern provinces and the entire Sassanian Empire, had been undertaken under the ministry of the Prophet and the Rashidun (the 'rightly-guided') Caliphs. ${ }^{47}$ And the practice of the Prophet and his Rashidun successors serve as the authoritative expressions of the law; ${ }^{48}$ or, rather,

\footnotetext{
${ }^{45}$ See M Cook, The Koran: A Very Short Introduction (OUP 2000) 35ff; AY Ali, The Meaning of the Holy Qur'an, (11 $1^{\text {th }}$ edn, Amana Publications 2008) 106.

${ }^{46}$ See DE Arzt, 'The Treatment of Religious Dissidents under Classical and Contemporary Islamic Law' in: J Witte; JD Vyver (eds.), Religious Human Rights in Global Perspective: Religious Perspectives (Vol. I, Kluwer Law International 1996) 412.

${ }^{47}$ There are some early battles of significance which expanded the reach of Islam. While narrations differ on their reasons, such wars include the Battle of Mu'tah (629), the conquest of Mecca (630), the expedition to Tabuk (630), the Ridda Wars (632-634); the Battle of Yarmouk (636); the Battle of al-Qadisiyyah (637), and the Battle of Nahavand (642). S Aoun, 'Le Jihad: le débat actuel sur la guerre et la violence' (2009) 19 Revue Internationale de Sociologie 509, $510 \mathrm{ff}$.

${ }^{48}$ See J Schacht, An Introduction to Islamic Law (OUP 1964) $10 \mathrm{ff}$.
} 
as an ideal paradigm for the manner in which divine injunctions should be understood. ${ }^{49}$ In fact, later Muslim polities modelled, in one way or another, on such practices as they expanded their territories by conquering foreign lands. ${ }^{50}$

Be that as it may, moderates perform an important function in seeking to revive critical thinking, and in denouncing sectarian violence that corrodes socio-political stability worldwide. Moderate scholars question the ostensibly immutable doctrines, and open controversial rulings on jihad to renewed interpretation with a view to undercutting warmongering hermeneutics. To their credit, they reject acts of wanton aggression and terrorism, insisting that they are diametrically opposed to the letter and spirit of the Quran, which declares: 'if any one slew a person-unless it be for murder or for spreading mischief in the land - it would be as if he slew the whole people: and if any one saved a life, it would be as if he saved the life of the whole people' (Q. 5:32). This verse indeed constitutes a resonant affirmation that the killing of the innocent is inexcusable regardless of all religious or political justifications. Sanctity of life was similarly accentuated by the Prophet, who equated murder with polytheism, a major profanity in Islam. He declared that: 'the greatest sins are to associate something with God and to kill human beings. ${ }^{51}$ Since terrorism generally harms civilians who have no direct bearing on the grievance complained of, it infringes the right to life, which ranks as one of the highest values in Islam. ${ }^{52}$

The same reasoning applies to suicide terrorism. As Kamali observes, 'since life is a God-given gift ... no one has the right to destroy it. [Hence] suicide is forbidden in Islam without any exception. ${ }^{53}$ One may also allude to a Quranic injunction which prohibits self-destruction $(\mathrm{Q}$. 4:29), and to the hadith narrated by Bukhari: 'A man was inflicted with wounds and he committed suicide, and so Allah said: "My slave has caused death on himself hurriedly, so I forbid Paradise for him."" 54 Another tradition reads: "[Whosoever] commits suicide by throttling shall keep on throttling himself in the Hell Fire (forever). ${ }^{55}$ Suicide is hence inimical to the overall ethos and mission of Islam. Over and above these reasons, terrorism defies Islamic humanitarian norms prohibiting disproportionate, unwarranted and indiscriminate force against civilian life, limb and property.

\footnotetext{
${ }^{49}$ See LJ Esposito, Islam: The Straight Path (OUP 1994) 13.

${ }^{50}$ See FM Donner, The Expansion of the Early Islamic State (Routledge 2016).

${ }^{51}$ Cited in: MI Ashra, Islamic Philosophy of War and Peace (iUniverse 2008) 110.

${ }^{52}$ See Q. 5:32.

${ }^{53}$ Kamali (n 26) 51.

${ }^{54}$ Hadith of Bukhari, Hadith 2:445.

${ }^{55}$ Ibid. Hadith 2:446.
} 
In light of the above, moderate arguments extolling the unwarlike forms of jihad are not without merit. It is further hard to disagree with such propositions that denounce terrorism, given the lack of any justification for indiscriminate killing in Islam. The abuse and misuse of jihad should not, therefore, give grounds for denouncing Islam as 'a religion of the sword [which] glorifies military virtues. ${ }^{56}$ Such a reductionist framing of Islam is highly problematic; for it dogmatically paints a monolithic, ahistorical and inherently aggressive paradigm of the religion itself. True, Islam is invoked as a reference point for the justification of fundamentalist violence. But the crux of the matter boils down to the manner in which literalist exegeses of selective source material is taken to an extreme point, where half-truths and out-of-context excerpts lead to a narrative legitimating irregular warlike jihad.

The above account has shown that the teachings of the moderate school essentially focus on the spiritual and defensive elements of jihad. While this school advances weighty arguments to shore up the point that Muslim conception of just war is compatible with contemporary use of force discourse, what is mainly absent from moderate works is critical and contextual analyses of the doctrinal as well as practical diversity within the Muslim tradition. Moderates generally eschew expounding on the nonlinear pronouncements on military jihad. As discussed below, Chapter 9 of the Quran contains some crucial verses authorising aggression against pagans and non-Muslim monotheists under certain circumstances. Indeed, unlike the Meccan injunctions, characterising the first phase of Islam (610-622 CE), the Medinan revelations (622-632 CE) incorporate a more assertive approach to warfare. And it is these sword verses (and traditions) that most expansionist Muslim empires did, and contemporary fundamentalists do, rely upon.

The burning question here is whether peaceful and bellicose verses dovetail; and, if not, whether the latter prevails over the former. The sword verses, such as Q. 9:5, Q. 2:191, Q. 9:123, Q. 8:65 and Q.47:4, do not appear to accord with the peaceable principles of non-compulsion, tolerance, or forgiveness. While the radical school gives pride of place to belligerent verses on grounds that the sword verses had abrogated verses of more conciliatory character, moderates propound that the application of these verses had been limited to pagan Arabs that were opposed to, or already at war with, the Muslims. ${ }^{57}$ Militant jihad, in this view, was restricted to thwarting aggression or persecution of hostile pagan forces that sought to overpower the Muslim polity in Medina. ${ }^{58}$ This

\footnotetext{
${ }^{56}$ SP Huntington, The Clash of Civilizations and the Remaking of World Order (Simon \& Schuster, 1996) 263.

${ }^{57}$ See SH Hashmi, 'War and Peace' in: SH Hashmi (ed.) Islamic Political Ethics: Civil Society, Pluralism, and Conflict (PUP 2002) 206-207.

${ }^{58}$ In Sachedina's words, 'it is not unbelievers as such who are the object of force, but unbelievers who demonstrate their hostility to Islam.' AA Sachedina, 'The Development of Jihad in Islamic Revelation and History' in: JT Johnson; J Kelsay (eds.), Cross, Crescent, and Sword (Greenwood Press 1990) 35, 43.
} 
line of reasoning fundamentally reiterates the defensive ethos of jihad. It is, however, clear that some Medinan verses (e.g. Q. 9:29) defy this customary moderate position.

\section{The Radical Reading of Jihad}

Classical works had generally paid scant attention to the spiritual dimensions of jihad. What in the main dominated scholarly debates, particularly until the 'closure of the doors' for ijtihad, ${ }^{59}$ had been the issue of legitimate war in protean political conditions. ${ }^{60}$ Following in the footsteps of most classical scholars, contemporary radicals likewise depict a pragmatic paradigm of jihad, where jihad may assume both combative and defensive colours. In other words, radicals gainsay the notion that warlike jihad incorporates self-defensive measures alone. To radicals, jihad is not merely a duty to defend Islam, but also a right to propagate thereof. While the radical thinking, which is not characterised by a monolithic approach, acknowledges the spiritual features of jihad, it stresses the mission of protecting, promoting and expanding Islam by all means. Depending on the dictates of conditions jihad might accordingly take a self-defensive or bellicose disposition.

One of the recurrent themes in radical circles is the notion of reinstituting Islam to its 'original' state. This is seen possible on condition that Muslims reject the secular political paradigm of the West, along with its 'decrepit' socio-moral values including consumerism, individualism and impiety. ${ }^{61}$ In their oversimplified worldview, all the major problems of the Muslim world, such as corruption, poverty and misrule, are attributable to the Muslim inability to revive the true Islam and resist Western conspiracies to halt Muslim progress. ${ }^{62}$ And since the West is said to hatch its devious plots against Islam through corrupt Muslim rulers, radical movements generally call for a confrontation with domestic co-conspirators. ${ }^{63}$ Nonetheless, especially since the early 1990 s, after the First Gulf War, jihadi movements, led by al-Qaeda, have come to lay more emphasis on engaging with the 'far enemy,' notably the United States (US). ${ }^{64}$ Jihad was therefore to be fought across borders, as the 'puppet' Muslim regimes were directed by external powers. ${ }^{65}$ Holding the US responsible for most ills on earth, bin Laden justified al-Qaeda atrocities under self-defence, claiming that it was the US which 'attacked us [first]. ${ }^{66}$ Targeting civilians was accordingly

\footnotetext{
${ }^{59}$ This process delivered a significant blow to critical thinking within the Islamic tradition. See O Bakircioglu, 'A Socio-Legal Analysis of Jihad' (2010) 59 ICLQ 413, 416.

${ }^{60}$ Peters (n 33) 79.

${ }^{61}$ See O Roy, 'L'échec de l'islam politique' (1992) 184 Esprit 106, 108-109.

${ }^{62}$ See B Lewis, The Jews of Islam (PUP 1984) 8ff.

${ }^{63}$ Such discourse is not peculiar to Sunni radicals alone. See F Hoveyda, The Shah and the Ayatollah: Iranian Mythology and Islamic Revolution (Praeger 2003) 82.

${ }^{64}$ Final Report of the National Commission on Terrorist Attacks Upon the United States, (WW Norton \& Company 2004), 59.

${ }^{65}$ See S Maher, Salafi-Jihadism: The History of an Idea (Penguin 2016) 42-43.

${ }^{66}$ Bin Laden's 'Letter to America' The Observer, 24 November 2002.
} 
legitimate, as the US citizens as a whole were vicariously responsible for supporting US policies in Muslim countries. ${ }^{67}$

It is worth noting that not all militants support the 'far enemy' strategy. The ISIS, in this respect, prioritised attacking the 'near enemy,' focusing at the same time on seizing as much territory and resources as possible. ${ }^{68}$ This notwithstanding, ISIS, despite its diminishing power and influence, seeks to launch sporadic attacks against the West. In the final analysis, despite tactical differences and non-linear trajectories, ${ }^{69}$ what is common to radicals is that they urge the establishment of a theocratic order wherein Sharia may apply to all fields of human activity. The goal of replacing all politically and religiously impoverished governments with truly 'Islamic' ones thus underpins the rhetorical subtext of radical Islamism. Linked with this objective is the aspiration to revive the caliphate, which is expected to play a significant role in transcending ethno-cultural divisions among the Muslims. ${ }^{70}$

Radicals, then, ultimately seek to construct theocracies as a way of achieving unison and piety in Muslim societies, as exemplified under the ministry of the Prophet and pious ancestors (salaf). ${ }^{71}$ Radical Islamists hence seek to promote a pristine vision of Islam, informed by the principles of the Quran and the practice of revered ancestors, rather than by man-made doctrines produced in various ages. ${ }^{72}$ The burning question here relates to the manner in which such a classical portrayal of Islam may be achieved. While radicals do not reject the idea of bottom-up approaches, they are not averse to top-down measures to obtaining political power that is deemed instrumental in materialising the requisite transformations. ${ }^{73}$ When controlled appropriately, radicals believe, the State would be a potent machinery for purifying the tradition, and building a politico-religious matrix poised to regulate all aspects of life — and hence also dismantling the Western socio-legal superstructure that is said to have contributed to the 'degeneration' of Muslim societies. ${ }^{74}$

\footnotetext{
67 Ibid.

${ }^{68}$ At the time of writing, ISIS is driven out (by the US-led coalition) of all the territory it once controlled. See The Guardian, 'Isis Defeated, US-backed Syrian Democratic Forces announce,' 23 March 2019. Available at: https://www.theguardian.com/world/2019/mar/23/isis-defeated-us-backed-syrian-democratic-forces-announce

${ }^{69}$ Al-Qaeda has recently placed a greater tactical focus on the 'near enemy.' J Burke, The New Threat from Islamic Militancy (Bodley Head 2015) 16-17.

${ }^{70}$ The caliphate was abolished in 1924 under the secular leadership of Atatürk. See H İnalc1k 'Büyük Bir Devrim: Hilâfetin Kaldırılması ve Lâikleşme' (1988) 3 Doğu Bati 71, 71-88.

${ }^{71}$ See JL Esposito, Islam and Politics (4th edn, Syracuse University Press 1998) 11.

${ }^{72}$ See O Roy, L'échec de l'islam politique (Points 2015) $35 \mathrm{ff}$.

${ }^{73}$ See K Ferdinand; M Mozaffari (eds.), Islam: State and Society (Routledge 1988).

${ }^{74}$ Radicals thus strive to undo the secularising reforms of past centuries. See B Lewis, 'Secularism in the Middle East,' (1995) 2 Revue de Métaphysique et de Morale 151, 160.
} 
Apropos the question of how jihad could be in the service of such ambitions, radicals submit that the emergence of a true Muslim polity cannot transpire through peaceful means alone. Inevitably, therefore, the emanation of God's sovereignty (hakimiyyah) to supersede those governments that are Muslim only in name would necessitate offensive jihad. ${ }^{75}$ Radical ideologues promulgate that jihad must above all be understood as a tool to fight aggression, injustice and imperialism. Hence, in contrast to moderates, radicals go beyond the self-defensive framework, advocating that jihad could be invoked to fight corruption and expanding the Muslim sphere of influence. It is on this account that terror groups like ISIS has stressed that jihad is a medium for restoring the greatness of Islam by deposing corrupt rulers, uprooting paganism and spreading Islam. ${ }^{76}$ The leader of alQaeda, Ayman al-Zawahiri, in this vein characterises jihad as a temporally and spatially unbound phenomenon geared toward an unceasing 'struggle between Truth and Falsehood. ${ }^{77}$ Evidently, such thinking blurs the line between defensive and offensive wars by glorifying all wars waged in the name of justice, defence and politico-religious expansion.

Despite the emphasis on jihad against oppression, corruption and imperialism, radicals also resort to jihad in the hope of restoring Islam to historical significance, which it once enjoyed particularly during the high medieval period. ${ }^{78}$ As alluded to earlier, the goal of reviving the Muslim strength walks hand in hand with that of restoring the caliphate as a unifying symbol for Muslim identity. ${ }^{79}$ It is from this vantage point that radicals criticise modern Muslim governments for having moved away from the ideal of instituting God's rule by undertaking profane practices and bringing about socio-political decadence. To the radicals, jihad against these governments is inescapable, for the circumstances can brook no compromise therewith.

\section{A. A Closer Look at Radical Thinking}

Radical criticisms and ambitions are not new. Despite the currency of bellicose rhetoric in recent decades, modern constructions of warlike jihad took shape notably after the colonisation of most Muslim countries by Europeans. Starting generally from the nineteenth century, Islamists sought to break the yoke of foreign domination by invoking jihad to address the waning power of Muslim polities that increasingly fell prey to imperial ambitions. ${ }^{80}$ The calls for militant jihad by Sayyid Ahmad of India, the Mahdist movement of Sudan, the Sanusiyya of Africa, and the Wahhabi

\footnotetext{
${ }^{75}$ See JA Turner, Religious Ideology and the Roots of the Global Jihad: Salafi Jihadism and International Order (Springer 2014).

${ }^{76}$ Bunzel (n 8) 10.

${ }^{77}$ AA Zawahiri, 'Four Years after the New York and Washington Raids' in: Ibrahim (n 2) 182.

${ }^{78}$ See B Lewis, What Went Wrong: Western Impact and Middle Eastern Response (Phoenix 2002).

${ }^{79}$ See İ Ortaylı, 'Hilafet Nasıl Kaldırıldı?' (2001) Popüler Tarih, 52, 52-57.

${ }^{80}$ See N Robinson, Islam: A Concise Introduction (Routledge 1999) 40ff.
} 
tradition of Saudi Arabia are illustrative of such appeals against colonialism. ${ }^{81}$ These movements, in a nutshell, stressed the superiority of militant jihad in the face of active external enemies and their local collaborators.

While experience with early colonialism engendered such reactionary ideas, more evolved forms of radicalism transpired in the twentieth century. A key figure to forge modern radical Islamism was Hasan al-Banna, who founded the Muslim Brotherhood in 1928. The Brotherhood emerged as a fervent reaction to imperialism in general, and to the British rule over Egypt in particular. ${ }^{82}$ Banna viewed all forms of foreign domination as anathema to Islam, considering it as one of the major sources of socio-economic deprivation. To Banna, Muslim political leaders had abandoned their duties towards their subjects, and hence it was incumbent on all Muslims to fight defensive wars. He declared:

Muslims today ... are subjugated by others and ruled by non-believers. Their lands have been trampled and their sanctities violated ... And so it is incumbent on all Muslims without exception to prepare, and to settle upon the intention of jihad and prepare for it until the opportunity arises... ${ }^{83}$

In addition to the call to drive out the 'infidels,' Banna's Brotherhood further aspired to liberate all Muslim countries, support global Muslim unity, and eventually to reinstitute 'pristine' Islam. ${ }^{84}$ Dismissing the moderate postulate that fighting baser impulses is the greater jihad, ${ }^{85}$ Banna wrote that the claim on the superiority of spiritual jihad only serves 'to deter people from the importance of fighting. ${ }^{86}$ Banna maintained that military struggle (qital) captured the very essence of jihad, a duty that is to be performed in an individual capacity like other fundamental acts of worship. ${ }^{87}$ It is to be noted that while jihad of individual duty (fard al-ayn) refers to the obligation of each able-bodied Muslim to fight in defence against aggression, ${ }^{88}$ jihad of collective duty (fard kifaya) demands the participation (in various forms) of Muslims as a community (in sufficient numbers) in cases of offensive wars. ${ }^{89}$ By calling on all war-worthy Muslims to fight as part of an individual duty, Banna simply accentuated the extraordinary nature of the threat facing Islam at the time.

\footnotetext{
${ }^{81}$ D Brown, 'Martyrdom in Sunni Revivalist Thought' in: M Cormack (ed.), Sacrificing the Self: Perspectives on Martyrdom and Religion (OUP 2001) 107, 109.

82 See CR Wickham, The Muslim Brotherhood: Evolution of an Islamist Movement (PUP 2013).

${ }^{83}$ HA al-Banna, 'Risalat al-Jihad (Epistle on Jihad)' n.d. cited in: T. Masoud, Counting Islam: Religion, Class, and Elections in Egypt (CUP 2014) 220.

${ }^{84}$ See AAM El-Awaisi, The Muslim Brothers and the Palestine Question: 1928-1947 (Tauris 1998) 135-137.

${ }^{85}$ To Banna, the dichotomy between the lesser and greater jihad was dubious. RP Mitchell, The Society of the Muslim Brothers (OUP 1969) 207-208.

${ }^{86}$ Cited in T. Masoud, 'The Muslim Brotherhood in Egypt,' in Esposito and Shahin (eds.) (n 1) 485.

${ }^{87}$ D Cook, Understanding Jihad (University of California Press 2005) 98.

${ }^{88}$ JT Johnson, Ethics and the Use of Force: Just War in Historical Perspective (Routledge 2011) 55.

${ }^{89}$ See J Kelsay, Arguing the Just War in Islam (HUP 2007) 138.
} 
Though Banna accepted that jihad was part of ijtihad, hence also comprising nonviolent means of striving, he scorned those who divested jihad of its belligerent attributes, reducing its military role to defensive measures alone. He noted that jihad had two key functions: to spread the word of Islam, and to defend Muslims from hostile incursions. ${ }^{90}$ Putting otherwise, unlike 'apologetic' scholars, he insisted that jihad had to be read in its principal sense of combatting, which required dedicated Muslim warriors willing to sacrifice their lives. If jihad was primarily warlike, it would follow that the highest form of martyrdom is attained through death sustained in just wars. ${ }^{91}$

Significantly, ideas about Muslim liberation through warlike jihad have left an indelible mark on contemporary radicals. In his letter to the Muslim youth, bin Laden invoked identical conceptions to mobilise his audience. 'Muslims,' he declared, 'are humiliated, tortured, and ruthlessly killed all over the world, and it is time to fight. ${ }^{92}$ Laden characterised any armed Muslim response as self-defence, an individual duty of 'each and every Muslim.' ${ }^{93}$ However, referring to the sword verse of (Q. 8:39), he depicted a very broad portrayal of self-defence which was indistinguishable from whole-sale aggression: 'The time has come,' he wrote, 'when [Muslims] ... should unite and soar against infidelity and continue jihad till these forces are crushed to naught, all the antiIslamic forces are wiped off from the face of this Earth, and Islam takes over the whole world and all the other false religions. ${ }^{, 94}$ Clearly, Laden co-opted and reconstructed the meaning of the said verse to justify his untenable position. The verse in fact envisages a limitation on the duration and scope of fighting in the following manner: 'And fight them on until there is no more tumult or oppression, and there prevails justice and faith ... [B]ut if they cease, verily Allah doth see all that they do.'

Banna's legacy left contemporary radicals with some other conceptualisations. His perception of the Brotherhood as an army of liberation charged with the sacred duty of reviving true Islam is a case in point — this figured in Mawdudi and Qutb's thinking discussed below. Likewise, Banna's pragmatic approach to the State apparatus as an instrument of forging a virtuous society is another example. The ideas of holding sway over the polity as an instrument of removing 'corrupt secular institutions,' and of reinstating faith at the heart of society are embraced by most radicals. Indeed, radicals consider the control of the State apparatus crucial in moulding a community of dedicated

\footnotetext{
${ }^{90}$ See Masoud (n 86) 485.

91 Al-Banna (n 83) 220; also see D Cook, Martyrdom in Islam (CUP 2007) 33.

92 OB Laden, 'Message to the Youth of the Muslim Nation,' 9 December 2001, in: BK Berner, Jihad: Bin Laden in his own Words, Declarations, Interviews and Speeches (Peacock Books 2007) 131.

93 Ibid.

94 Ibid.
} 
believers. ${ }^{95}$ The corollary of this position is that governments were legitimate only if they had a clear agenda of bringing about the socio-political changes demanded by the radicals.

Evidently, radical Islamism is a diverse phenomenon with divergent shades. But the core notions of Banna have consistently figured in the works of other Muslim thinkers. Mawdudi, the founder of the Jamaat-e-Islami, similarly shaped his ideas against the backdrop of anti-colonial struggles experienced in British India. ${ }^{96} \mathrm{He}$ opined that humankind was enchained by the slavery of manworship: 'wherever you turn your eyes,' he said, 'you will find that one nation dominates another, one class holds another in subjection. ${ }^{97}$ Priority must accordingly be given to submission to God, and to the restoration of divine sovereignty on earth; for 'the root-cause of all evil and mischief in the world is the domination of man over man. 98

Mawdudi dismissed the possibility of positive change in Muslim societies, unless corrupt agents of the jahiliyyah (i.e. pre-Islamic ignorance and immorality) were removed from their usurped positions of power, whereby they instigated immoral and iniquitous practices. ${ }^{99}$ As with Banna, Mawdudi was not loathe to top-down Islamisation through the State machinery. And his vision of political philosophy was 'the very antithesis of secular Western democracy,' where 'absolute powers of legislation [rested] in the hands of the people. ${ }^{100}$ He noted that 'in the Islamic political theory this right vests in Allah alone,' ${ }^{101}$ which, however, could be exercised by God's vicegerent (caliph) on earth. ${ }^{102}$ The notion of secularism was anathema to Islam, since politics was not only an 'inseparable part of the faith,' but it could be a 'panacea' for all the problems Muslims face. ${ }^{103}$

Taking this stance to its extreme, ISIS has sought to establish a State (an unprecedented step for a terror organisation), so that it could have a base for its operations, raise revenues and impose its extremely militant vision of Islam over those unfortunate enough to have fallen under its rule. Mawdudi had probably no intention of inspiring a barbarous group such as ISIS. Yet what he advocated was that the five pillars of Islam were essentially preparatory phases of military jihad,

\footnotetext{
95 The Brotherhood had a pragmatic approach toward the ballot-box to effectuate change. Masoud (n 86) 482-493.

${ }^{96}$ See I Ahmad, Islamism and Democracy in India (PUP 2009) 49-82.

${ }^{97}$ SAA Mawdudi, The Islamic Law and Constitution K Ahmad (trans.), (Islamic Publications, nd) 134; CJ Adams, 'Mawdudi and the Islamic State' in: JL Esposito, Voices of Resurgent Islam (OUP 1983) 103.

98 Mawdudi (n 97) 133.

${ }^{99}$ Ibid. 102.

${ }^{100}$ Ibid. 138.

101 Ibid.

102 Ibid. 139.

${ }^{103}$ SAA Mawdudi, Fundamentals of Islam (Islamic Publications 1975) 249-250.
} 
which had to be fought to obliterate all un-Islamic systems and propel humanity towards greater peace, freedom and moral fortitude. ${ }^{104}$

Syed Qutb inaugurated a more hard-line brand of radicalism that has hitherto inspired a multitude of militant groups - of particular significance, al-Qaeda and ISIS have in the main followed his intellectual trajectory. ${ }^{105}$ The general framework of Qutb's political philosophy was influenced by Mawdudi and the thirteenth-century thinker Ibn Taymiyya. As with most radicals, Qutb had been critical of capitalism and the manner in which Western politico-cultural superstructure affected Muslim societies. In his well-known book, Milestones, he drew a bleak picture of human condition by noting that 'mankind today is on the brink of a precipice' for lack of a system where religious values could be intrinsic to State and society. ${ }^{106} \mathrm{He}$ declared that the modern world was steeped in the 'vast ocean' of jahiliyyah. ${ }^{107}$ Referring to pre-Islamic practices of ignorance, Qutb hence sought to draw attention to 'sacrilegious' customs of modern societies, which, he lamented, failed to honour such values that distinguished humans from animals. ${ }^{108}$

To Qutb, Muslims in their current state of material weakness and political decay had shamefully plunged into lawless, immorality and tyrannical ignorance, which, as his intellectual predecessors highlighted, required the restoration of Islam to its original state. ${ }^{109}$ Qutb, in this respect, exhorted Muslims to free themselves from the clutches of jahili polities, and to follow 'in the footsteps of the first generation of Muslims through whom God established His system and gave it victory over jahiliyyah. ${ }^{110}$ Yet since the entire socio-legal edifice of jahiliyyah was 'based on rebellion against God's sovereignty on earth,' the custodians of corruption would not relax their firm grip on power without a bitter fight. ${ }^{111}$ Despite the desirability of peaceful means, Qutb thus deemed bellicose jihad unavoidable to depose the usurpers of power, and deliver humans from servitude to anyone other than God. ${ }^{112}$ This clearly meant that jihad could well assume an offensive posture to obtain tangible results.

\footnotetext{
${ }^{104}$ AA Mawdudi, 1997b. 'Jihad fi Sabilillah' 3-9; cited in: D Zeidan, The Resurgence of Religion: A Comparative Study of Selected Themes in Christian and Islamic Fundamentalist Discourses (Brill 2003) 237; also see SVR Nasr, Mawdudi and the Making of Islamic Revivalism (OUP 1996) 83.

${ }^{105}$ See M Scheuer, Osama Bin Laden (OUP 2011) 34ff.

${ }^{106}$ S Qutb, Milestones (Islamic Book Service 2001) 7ff.

${ }^{107}$ Ibid. 12.

108 Ibid. 98.

${ }^{109}$ Ibid. 9-15.

${ }^{110}$ Ibid. 22.

111 Ibid. 11.

112 Ibid. 59.
} 
In response to the assertion that militant jihad is restricted to self-defensive wars, Qutb argued that Islam has never been a defensive movement. By contrast, he noted, 'it is the right of Islam to release mankind from servitude to human beings so that they may serve God alone. ${ }^{113} \mathrm{He}$ scorned those moderates who assumed an apologetic tone while discussing the meaning of jihad. Indeed, he challenged the notion that Islam was devoid of a combative spirit; for it was the spirit of conquest that cemented Islam as a global actor. ${ }^{114}$ From this perspective, he branded moderates as spiritually and mentally defeated owing to the pressure of "vicious orientalists." ${ }^{115} \mathrm{He}$ accused them of playing down the key colours of jihad, and of reducing Islam to a mere belief system. ${ }^{116}$ Islam, by contrast, had 'a God-given right to ... take control of the political authority so that it may establish the Divine system on earth. ${ }^{117}$ In a nutshell, then, he vehemently inveighed against those who were reluctant to acknowledge 'that offensive jihad [was] one of the exclusive traits of [Islam], ${ }^{, 18}$ whereby justice and divine sovereignty on earth may materialise.

Qutb's rhetoric has hitherto inspired many radicals who turned against the West, as well as their own governments denounced as jahili. ${ }^{119}$ Yet however unique Qutb's discourse may appear, his denunciation of most modern polities as 'anti-Islamic' or 'ignorant' owes its intellectual genesis to the ideas of a $13^{\text {th }}$ century scholar, Ibn Taymiyya (d.1328). Confronted with the question of whether Muslim subjects could launch jihad against avowedly 'Muslim' rulers, Taymiyya held that a mere profession of Islam was inadequate unless the supposed Muslim polity applied Sharia laws in an all-embracing fashion. Having Mongol Muslim converts in mind, Taymiyya argued that whilst internecine wars amongst Muslims are impermissible, ${ }^{120}$ because 'the Mongols ... are rebellious against the laws of Islam, fighting them is obligatory.' ${ }^{121}$

A major problem with Taymiyya's logic lay in its defiance of the Muslim dictum that only God may judge sincerity in belief. This thinking necessitates a subjective assessment of whether an outwardly pious act (profession of creed) was twinned with religious sincerity. Such a judgement is supposed to come from God alone. ${ }^{122}$ Taymiyya's reasoning was largely informed by his desire

\footnotetext{
113 Ibid. 75.

${ }^{114}$ See MO Carré, 'Le combat-pour-Dieu et l'État islamique chez Sayyid Qotb, l'inspirateur du radicalisme islamique actuel,' (1983) 33 Revue Française de Science Politique 680, 687ff.

115 Qutb (n 106) 76.

116 Ibid. 48.

${ }^{117}$ S Qutb, Milestones (Islamic Book Service: 2001) 76.

118 Ibid. 59. Bin Laden also denounced moderate Islam 'as a prostration to the West.' Bin Laden (n 2) 22-62.

119 See K Armstrong, Islam: A Short History (Phoenix Press 2002) 145ff.

${ }^{120}$ See Fadl (n 3) 63.

${ }^{121}$ Ibn Taymiyya, Majmu'a Fatawa, IV, 299, para. 42; cited in: J Jansen, 'Ibn Taymiyyah and the Thirteenth Century: A Formative Period of Modern Muslim Radicalism' (1988) 5 Quadreni di Studi Arabi 391, 395.

${ }^{122}$ See Q. 6:57; Q. 39:46; Q. 2:113; Q. 60:10; Q. 27:74-78; Q. 13:42.
} 
to drive the Mongol invaders out of Muslim lands. Yet his proposition of distinguishing the truly pious from the impious has inspired radical Islamists to fight those they accused of disbelief and apostasy. ${ }^{123}$ Another problem with the idea of differentiating the pious from the impious is that this might spur fratricidal wars of political control, which Islam in principle discourages in favour of stability and order. As Lewis observes, 'the demand of Islam from the believers is not textual accuracy in belief but loyalty to the community and its constituted leader.' ${ }^{124}$ The Quran supports this: 'O ye who believe! Obey Allah and obey the Messenger, and those charged with authority among you' (Q. 4:59)?

Likewise, various traditions recognize the merits of deferring to political power. Such traditions mainly stress the idea that 'any ruler is better than chaos,' ${ }^{125}$ irrespective of the roots and justness of his power - albeit rulers are encouraged to observe the tenets of natural justice. If, then, a ruler acts in contempt of justice, he must not be deposed lest a civil strife (fitna) should ensue, a feared consequence which is assumedly worse than arbitrary rule. Responding to a question about how Muslims should react toward a ruler, the Prophet had reportedly replied: 'True religion is being faithful to God, His book, and to the imams of the Muslims. ${ }^{126}$ The Prophet is likewise narrated to have told: 'whoever obeys my amir obeys me; and whoever disobeys my amir disobeys me.' 127 The duty to obey is said to apply to such rulers that do not follow the holy guidance. The Prophet is reported to have remarked: 'There will be after me imams who do not follow the true guidance (huda) and do not imitate my example (Sunna) ...' This notwithstanding, the Prophet counselled, Muslims were to 'hear and obey [such an] emir, even if [their] back[s] [were] whipped.' 128

However, caution must yet be exercised about this matter, as the question of legitimate leadership and its permissible limits remains equivocal. There are indeed some traditions tempering the duty to obey unqualifiedly. Some narrations, for instance, stress that while unjust leaders are not to be supported, they must not be fought as long as they worship God. ${ }^{129}$ There are other traditions that decree that no obedience is owed to a ruler who acts in disobedience to $\operatorname{God}^{130}$ - although what

\footnotetext{
${ }^{123}$ For assassination examples of those accused of apostasy and disbelief, see Kepel (n 7) 287.

${ }^{124} \mathrm{~B}$ Lewis, Islam and the West (OUP 1994) 178.

125 This maxim is attributed to al-Ghazali. See A Hourani, Arabic Thought in the Liberal Age: 1798-1939 (CUP 1962) 14.

${ }^{126}$ Ahmad ibn Hanbal, Musnad, XV, 99-100 (no. 7941).

${ }^{127}$ Ibid. XIV, 76 (no. 7643).

${ }^{128}$ Sahih Muslim, Book XX, Hadith 4554.

${ }^{129}$ Sunan al-Tirmidhi (Jami al-Tirmidhi), Book IV, Ch. 72, No. 2259 458, and Ch. 78, No. 2265.

${ }^{130}$ Sahih al-Bukhari 6830, Șahih Muslim 1840.
} 
constitutes 'disobedience' remains unclear. And some traditions exhort Muslim rulers to be kind and generous to his subjects. ${ }^{131}$

None of these traditions encourages rebellion against the rulers. But they are nonetheless invoked by radicals against those leaders deemed oppressive. These radicals, however, do not address the issue of who determines whether a polity is imbued with corruption and injustice, or whether the ruler no longer worships God. A further obscurity concerns the manner in which the discontented should resort to forceful measures to depose a sinful leader. Again, who could guarantee whether the next ruler would avoid evil by doing justice or by putting the interests of the believers ahead of his own interests? Such thorny questions underscore the indeterminate and contested nature of leadership in Muslim thought. A lack of convincing answers to these questions arguably lend credence to the orthodoxy that obedience to the (unjust) ruler is preferable over chaos. Hourani, in this context, posits that the view that any ruler is better than anarchy carries the message that 'political power is ... from God, and must be obeyed.' ${ }^{132}$ Be that as it may, a preference to eschew the bitter consequences of a forceful regime change would inevitably play in the hands of powerholders. Evidently, had there been explicit guidelines on political leadership in the Quran and the hadith literature, traditionalists and radicals would have had less opportunity to play one set of verses or traditions against another in a bid to maintain or alter the status quo.

It must by now be clear that what most radicals demand is to expurgate impurities imposed upon Islam by alien or apostate forces, and to restore a pure Islamic public order. Militant jihad in this scheme of things is seen as an unavoidable evil geared towards midwifing desired objectives. Radicals thus see themselves as puritans who are intent on restoring the piety of the early Muslim community. ${ }^{133}$ They call on their followers to wage all forms of jihad against decadence, injustice and oppression. However, at the hands of militants, the call for such jihad might provide a licence for forceful conversions, top-down regime changes, territorial conquests, killing and enslaving of perceived enemies, pagans or apostates, or levying poll-taxes (jizya) on non-Muslim minorities of monotheistic traditions. ${ }^{134}$

\footnotetext{
${ }^{131}$ Sahih Muslim, Kitab al-Imara, Book 20, No. 4493. For related hadiths, see FM Donner, Narratives of Islamic Origins: The Beginnings of Islamic Historical Writing (The Darwin Press 1998) 40-44.

132 Hourani (n 125) 14.

${ }^{133}$ See WM Watt, Muhammad: Prophet and Statesman (OUP 1964) 214-220.

${ }^{134}$ ISIS has branded all Shiites, Yazidis, Druze, Alawites and Sufis as devil worshippers or apostates whose killing or enslavement was legitimate. See B Haykel, 'ISIS and al-Qaeda: What are They Thinking? Understanding the Adversary’ 668 Annals, AAPSS, November 2016, 71, 75.
} 


\section{B. Offensive Jihad and the Doctrine of Abrogation}

Whilst the above-discussed 'unapologetic' views provide the major reference points for radicals, proponents of offensive jihad support their views by reference to other doctrines too. As alluded to earlier, among the apologists of militant jihad, there are those that maintain that peaceful verses of the Meccan period had later been abrogated by the sword verses of Medina, ${ }^{135}$ where under the leadership of the Prophet Muslims had become a force to be reckoned with. Islamic exegetical tradition initially used the method of abrogation (naskh) to explicate the ostensibly conflicting passages of the Quran by linking disputed verses with those traditions associated with specific historical episodes. ${ }^{136}$ To the upholders of this method, divine revelations had been imparted in response to specific predicaments faced by the Prophet and his followers. God is hence believed to have guided the Muslims through His varying or flexible revelations in uncertain times. When there appears an apparent contradiction amongst the verses, it is suggested that the earlier verses should be considered to have revealed in response to the contingency of the incident, whereas the subsequent revelations should be deemed normative and binding. ${ }^{137}$ In cases of disagreement between the verses, therefore, the subsequent ones are deemed to have abrogated the earlier ones.

The abrogation theory might be traced to the Quran: 'None of Our revelations do we abrogate or cause to be forgotten, but We substitute something better or similar ...' (Q. 2:106). This verse may be construed to suggest that a revelation could be replaced by another when the exigencies of the times had so warranted. It is unclear, however, whether the subsequent verse axiomatically supersedes the earlier one-albeit there is room for such thinking. It may further be speculated that this verse refers to earlier revelations of other monotheistic societies, which are believed to have been superseded by the Quran. There are other suggestions that the verse involved came in response to the hermeneutical challenges mounted by non-Muslim critics about the consistency of the Quran. ${ }^{138}$ The following verse appears to engage with such a critique, attesting that God might permit progressive revelation: 'When We substitute one revelation for another, and Allah knows best what He reveals (in stages), they say, "thou art but a forger:" but most of them understand not' (Q. 16:101).

If the Quran is conceived to stand in perfect harmony, then the theory of abrogation would clearly lose some ground. The tone of Meccan and Medinan verses on jihad, however, evidently differs.

\footnotetext{
${ }^{135}$ See L Fatoohi, Abrogation in the Qur'an and Islamic Law: A Critical Study of the Concept of "Naskh" and its Impact (Routledge 2013) 3.

${ }^{136}$ See O Leaman (ed.), The Qur'an: An Encyclopaedia (Routledge 2006) 5.

${ }^{137}$ Firestone (n 10) 49-50.

${ }^{138}$ See S Carimokam, Muhammad and the People of the Book (Xlibris Corporation 2010) 257.
} 
To explicate this variance, proponents of aggressive jihad advance the idea of progressive divine guidance by drawing attention to Chapter 9 of the Quran that embodies many prominent 'sword' verses revealed in circa 631 - a year before the demise of the Prophet when he was at the height of his politico-religious influence. ${ }^{139}$ Because Chapter 9 authorises the sword against polytheists (unless they embraced Islam or concluded a peace treaty with Muslims), ${ }^{140}$ and also against nonMuslim monotheists (unless they paid a poll-tax), ${ }^{141}$ these commentators argue that Chapter 9 abrogated previous revelations that required Muslims to accommodate other monotheists, display tolerance towards those rejecting Islam, and employ peaceful means to settle disputes. ${ }^{142}$ It is, in short, propounded that belligerent verses had taken precedence over the peaceable ones. ${ }^{143}$

It follows from this postulation that Q. 2:256 (the no-compulsion rule) had been abrogated by Q. 9:73 with regard to polytheists, and by Q. 9:29 concerning the 'People of the Book' (non-Muslim monotheists). ${ }^{144}$ It was hence posited that whilst the 'no compulsion' rule formerly meant the prohibition of force against non-Muslim believers, following the revelation of the sword verses its ruling had not been fully enforced. Some jurists went so far as to contend that warlike verses had abrogated some 114 peaceful verses, spread into 54 Chapters, which had until then regulated peaceful relations with non-Muslims. ${ }^{145}$

Advocates of abrogation also maintain that the prominent sword verse of Q. 9:5 epitomised a sea change in the progressive scheme of divine guidance; as the verse was revealed after the violation of the Hudaybiyyah Agreement (which envisaged a ten-year-long truce) by the Meccan enemies of Islam. ${ }^{146}$ This verse called on Muslims to fight the Meccan pagans until they had repented and established regular prayers. ${ }^{147}$ In support of the idea that Q. 9:5 brought about a dramatic change in strategy, Friedmann postulates that the deeds of the Prophet generally followed the lead of the sword verses, which mainly enjoined Muslims to adopt lethal measures when dealing with nonMuslims. To Friedmann, the Prophet had in effect presented the Arab pagans with the choice of

\footnotetext{
139 See Fatoohi (n 135) 119ff.

${ }^{140}$ Q. 9:7.

${ }^{141}$ Q. 9:29.

142 See D Bukay, 'Peace of Jihad? Abrogation in Islam' (2007) 14 MEQ 3-11.

${ }^{143}$ MA Kazleh, 'Rethinking International Relations Theory in Islam: Toward a More Adequate Approach' (2006)

5 Turkish Journal of International Relations 41, 43.

${ }^{144}$ These included the Jews, Christians and the Sabians (Q. 2:62).

145 See MAS Faraj, 'The Neglected Duty' in: RL Euben; MQ Zaman (eds.), Princeton Readings in Islamic Thought: Texts and Contexts from al-Banna to bin Laden (PUP 2009) 327, 338-339.

146 See M Ruthven, Islam in the World ( $3^{\text {rd }}$ edn, OUP 2006) $57 \mathrm{ff}$.

${ }^{147}$ See Kamali (n 53) 46; JE Brockopp, 'Introduction' in: JE Brockopp (ed.) The Cambridge Companion to Muhammad (CUP 2010) 10.
} 
conversion or the sword. The Prophet, the argument went, would not have acted as such had he felt compelled to follow the principle of non-compulsion. ${ }^{148}$

Plausible though such arguments are, recall that the Quran does not, whether expressly or tacitly, annul any of its verses; nor does it specifically substitute one particular verse for another. Indeed, there exists no explicit verse clarifying such injunctions that are either annulled or superseded by the subsequent ones. More importantly, divine injunctions of the early period, some of which are said to have been set aside, are not solely germane to matters of war and peace, but to the overall normative and ethical framework of Islam, which is characterised by such vital notions as peace, justice, equity, tolerance, patience, respect and fairness. And it is by reference to such values that Muslims have sought to define their personal, national and international relations. Consequently, the unqualified verdict that subsequent verses have perforce abrogated the previous ones is highly questionable.

In further support of the argument that the Quran should not be robbed of its peaceable principles arbitrarily (with a consequence of its ethical matrix being gravely impaired), it may be submitted that God cannot be conceived as having revealed both timeless principles and opposing principles of temporary nature about the same matter. Rather, it is more plausible to surmise that He guided the embryonic Muslim community through injunctions responsive to varying challenges faced at different times. Viewed from such a contextual prism, peaceful verses arguably remain operative, and thus applicable to the changing dynamics of international relations.

\section{The House of Islam versus the House of War}

Another critical military doctrine, on which radical Islamists rely, categorically divides the world into two broad domains: the House of Islam (dar al-Islam), wherein holy Muslim laws prevail, and the House of War (dar al-harb), which comprises the entire non-Muslim world. This doctrine had been formulated during the imperial age of Islam, ${ }^{149}$ which has often been used to legitimise offensive jihad as an instrument of dealing with material or putative enemies, and of expanding the influence of Islam.

While such a rigid bifurcation of the world lacked scriptural backing, it carried the signatures of such canonical scholars as Abu Hanifa (d. 767) and Abu Yusuf (d. 798), who argued that because there had been a permanent state of war between the Islamic and non-Islamic realms, the House

\footnotetext{
${ }^{148}$ See Y Friedmann, Tolerance and Coercion in Islam: Interfaith Relations in the Muslim Tradition (CUP 2003) 102.

${ }^{149}$ See AK Bennison, The Great Caliphs: The Golden Age of the Abbasid Empire (Tauris 2011).
} 
of Islam was invariably justified in fighting the House of War until the latter embraced Islam or paid the poll tax. ${ }^{150}$ Evidently, such a perpetual conception of war, punctuated only be temporary truces, has historically legitimated wars that were religious or political in nature. ${ }^{151}$ Theoretically, the doctrine requires Muslims to impose Sharia over the entire world, a quest to be pursued until it has been achieved. ${ }^{152}$ Since such a bifurcation of the world implies that Islam faces a constant threat of warfare from non-Muslims, Muslims are assumedly justified in bringing the domain of unbelief under the sway of a universal Islamic polity.

Given its grave implications, it is worth looking into the justificatory roots of the doctrine. Absent scriptural justification, the doctrine is often traced to a tradition attributed to the Prophet, wherein he reportedly uttered: 'Unbelief is one nation.' ${ }^{153}$ Yet since the historical accuracy and meaning of this saying remains controversial, ${ }^{154}$ it appears injudicious to infer that the non-Muslim world as a whole must be coerced into submission. For neither the Quran nor the Sunna envisages such a monolithic distinction between the domains of 'Islamdom' and 'Heathendom,' with temporally and spatially unrestricted bellicose implications. ${ }^{155}$ It is thus plausible to suggest that this juristmade doctrine is a child of circumstance, reflecting the political and military realities of its time. Carrying the hallmarks of imperial strength, the 'perpetual war theory' stands in contrast to the tolerant face of Islam with its ambition to foster an exclusive religious identity with a potential to perpetuate belligerency against all non-Muslims.

As the historical record of Muslim State practice illustrates, however, the doctrine has never been fully implemented. ${ }^{156}$ In fact, ever since the demise of the Prophet and his early successors, there had hardly been any political unity within the Muslim world, which had splintered into rival sects and contending polities across the globe. The customary practice of signing treaties of peace and commerce with non-Muslim entities throughout history ${ }^{157}$ further evinces that the doctrine had not taken to mean unceasing or perpetual war. Even during the age of sweeping military victories, Muslim rulers and jurists did recognise the practicality and legitimacy of non-hostile mechanisms of international affairs. ${ }^{158}$ And this was made possible in view of the flexible nature of Islamic

\footnotetext{
${ }^{150}$ M Khadduri, The Islamic Law of Nations: Shaybani's Siyar (John Hopkins Press 1966) 52-54.

${ }^{151}$ See FM Bonner, Jihad in Islamic History: Doctrines and Practice (PUP 2006) 122-123.

152 See J Kelsay, Islam and War: A Study in Comparative Ethics (John Knox Press 1993) 34.

153 B Lewis, Politics and War in Islam (Princeton: Princeton University Press 1975) 174-175.

154 JR Smith, The Crusades, Christianity, and Islam (Columbia University Press 2008) $71 \mathrm{ff}$.

${ }^{155}$ See M Abbès, 'Guerre et paix en islam: naissance et évolution d'une "théorie"' (2003) 73 Mots: Les langages du politique 43, 51 .

${ }^{156}$ See M Hamidullah, Muslim Conduct of State ( $5^{\text {th }}$ edn, Ashraf Press 1968).

${ }^{157}$ See AA An-Na'im, Toward and Islamic Reformation: Civil Liberties, Human Rights, and International Law (Syracuse University Press 1996) 150.

${ }^{158}$ See M Khadduri, 'Islam and the Modern Law of Nations' (1956) 50 AJIL 359ff.
} 
international law (siyar), which, unlike most areas of Sharia law, was forged within the mould of juridical deliberations consistent with tangible political realities. ${ }^{159}$ Although such jurisprudence had to conform to the fundamental tenets of Islam, this did not affect that siyar had largely been man-made, and as such not immutable or timeless. As Badr highlights, 'the Islamic law of nations is not part of the dogma of Islam, but is the product of a continuing process of juridical speculation by authoritative jurists over the ages. ${ }^{, 160} \mathrm{He}$ adds that siyar has always adapted to the evolving dynamics of international relations during the Islamic ages of 'expansion,' 'interaction,' and of 'coexistence.' ${ }^{161}$ In brief, then, there has never been a rigid framework of siyar, which has taken its non-linear structure against the backdrop of changing conditions on the ground. Hence, any serious effort to understand the Muslim approach to international relations must pay special attention to the relevant historical context and Islamic reactions thereto.

This living aspect of siyar challenges the idea that the medieval theory of perpetual belligerency reflects the irrefutable expression of God. Arguably, such a hypothetical bifurcation of the world have never stood on solid ground due in large part to the continuous political schisms within the House of Islam. As noted above, the disintegration of Muslim unity started right after the rule of the Prophet's immediate successors, ${ }^{162}$ notably with the emergence of the Sunni and Shiite divide on the question of legitimate leadership, which has over the centuries triggered many internecine conflicts. Furthermore, since its inception Islam has attracted countless believers across the globe with contending interests, and rival claims over politico-religious authority. ${ }^{163}$

Taken together, it appears that the ostensibly unified 'House of Islam,' which is in a state of open and constant hostility with the so-called 'House of War' is a legal fiction, rather than a compelling reality. Today, the doctrine of perpetual belligerency is more problematic given the rich ethnocultural and denominational variety within Islam - a religion embraced by divergent nations that are occasionally at daggers drawn with one another over politically thorny issues. In a word, then, this bellicose and 'time-bound' theory is untenable in large measure due to its inability to capture the broader framework of Muslim realpolitik. Assuming the contrary would only hold Muslims hostage to inflexible, man-made dogmas that are unresponsive to the dictates of fluid sociopolitical conditions.

\footnotetext{
${ }^{159}$ See FA Hassan, 'The Sources of Islamic Law' (1982) 76 American Society of International Law Proceedings 65,68

${ }^{160} \mathrm{GM}$ Badr, 'A Survey of Islamic International Law' (1982) 12 ASIL 56, 56.

161 Ibid. 56.

${ }^{162}$ See P Sarris, Empires of Faith: The Fall of Rome to the Rise of Islam, 500-700 (OUP 2011) 263-272.

${ }^{163}$ See HM Gwatkin, The Cambridge Medieval History (Vol. IV-I, Macmillan 1966) 699; H İnalcık, Osmanlılar: Fütühat, Imparatorluk, Avrupa ile İlişkiler (Timaş Yayınları 2010) 115.
} 


\section{Rethinking Partisan Doctrines}

As the above account has shown, the scope of jihad goes beyond the confines of peaceful striving by comprehending the use of force under certain circumstances. A significant point to detail here, however, is that one of the basic objectives of warlike jihad is to combat pagans until they have repented and accepted Islam. Whilst Muslims are obliged to call others to Islam, those who hold monotheistic beliefs ('People of the Book') are normatively exempt from coercion on conditions that they avoid proselytising their beliefs and pay a poll-tax (jizya). ${ }^{164}$ The fulfilment of this extra financial duty allowed non-Muslim monotheists of conquered lands to practice their faiths in a generally protected environment, wherein they did not have to perform military service. ${ }^{165}$ True, conquests played a large role in expanding the sphere of Islam. But Muslims would normally set off on military campaigns against monotheists only when their invitation to Islam or demand of the poll-tax had been rejected. Thus, the focal concern was not to impose Islam at sword point on those who revered the Holy Scriptures that Muslims recognised. Scriptuaries would rather be given a freedom to adopt Islam, or to retain their faiths by accepting the status of protected people (dhimmi) with its accompanying civic and fiscal obligations. ${ }^{166}$

While dhimmis did not historically stand on equal legal footing with their Muslim counterparts, ${ }^{167}$ they were in the main accorded a fair degree of liberty and tolerance with no comparable parallel in Medieval Europe. ${ }^{168}$ Muslims were urged to respect the customs of such protected groups. The Ottoman Empire's millet system provides a case in point concerning the distinct attitude toward recognised communities (millets) that were granted a reasonable level of religious autonomy. ${ }^{169}$ The millet system also provided a degree of legal pluralism which entitled denominational groups to enforce their laws, particularly in matters of family law, personal status and succession. ${ }^{170}$ The system further empowered these groups to practice their rites, establish communal organisations, and regulate their education system, provided that such activities did not breach Sharia norms. ${ }^{171}$

\footnotetext{
${ }^{164}$ The system of levying jizya is abolished in almost all Muslim countries. See Y Courbage; P Fargues, Chrétiens et juifs dans l'islam arabe et turc (Payot 2005) 153.

${ }^{165}$ See R Peters (ed. and trans.), Jihad in Medieval and Modern Islam (Brill 1977) 51.

166 See Khadduri (n 150) 159.

${ }^{167}$ Muslims believe that the Quran is God's final effort to reconstruct the 'original,' but long-forgotten, message preached by Prophets since Abraham. See Q. 2:127-130; J Berkey. The Formation of Islam: Religion and Society in the Near East, 600-1800 (CUP 2003) 48.

168 As Lewis observes, 'there is nothing in Islamic history to compare with the massacres and expulsions, the inquisitions and persecutions that Christians habitually inflicted on non-Christians and still more on each other.' BW Lewis, The Multiple Identities of the Middle East (Schocken Books 2001) 129.

${ }^{169} \mathrm{H}$ İnalcık, 'The Status of the Greek Orthodox Patriarch under the Ottomans' in: H İnalcık (ed.) Essays in Ottoman History (Eren 1998) 195-223.

${ }^{170}$ See H İnalc1k, Osmanlı'da Devlet, Hukuk ve Adalet (Kronik Kitap 2017) 47.

${ }^{171}$ See B Masters, Christians and Jews in the Ottoman Arab World: The Roots of Sectarianism (CUP 2001) 61.
} 
Although military and political power decidedly rested with Muslims, non-Muslims had notable impact on the management of economic life and, in part, on the political process. ${ }^{172}$

In a nutshell, then, on account of their special status, Muslims are enjoined to respect the 'People of the Book,' and invoke lethal measures only when they fail to secure their religious conversion, or payment of extra taxes. ${ }^{173}$ This somewhat privileged situation was not, in principle, applicable to polytheists, however. In Lewis' words, 'for those who were not monotheists and possessed no recognised scriptures, the alternatives were harsher; ${ }^{174}$ as one of the key motives of jihad was to proselytise pagans through peaceful or lethal measures. ${ }^{175}$ Again, the customary practice was to invite the pagans to Islam first. ${ }^{176}$ Khadduri, in this context, writes that polytheists had a narrow choice of either embracing Islam or facing the sword; and thus they could not opt to pay the polltax. This, Khadduri adds, was on account of several sword verses that enjoined Muslims to 'fight and slay the pagans wherever [they were found];' (Q. 9:5) to 'fight the unbelievers [firmly];' (Q. 9:123) and to 'smite at their [pagans'] necks' when they were met in combat (Q. 47:4). Khadduri supports his point by referring to a tradition ascribed to the Prophet narrated by Muslim ${ }^{177}$ - a canonical hadith reporter: 'I have been commanded to fight against people [pagans] till they testify that there is no god but Allah... ${ }^{178}$ Khadduri's argument accords with that of Shafi, who posited that since the option of paying the poll-tax was limited to Scriptuaries, pagans had to be fought until they embraced Islam on pain of death. ${ }^{179}$

The Islamic position on pagans, however, appears to have more complexity than what Khadduri and Shafi suggest. Both of them, in fact, failed to cite another noteworthy tradition, again narrated by Muslim, where the Prophet is reported to have allowed polytheists to pay the jizyah:

When you [Muslims] meet your enemies who are polytheists, invite them to three courses of action. If they respond to any one of these, you ... withhold yourself from doing them any harm. Invite them to (accept) Islam; if they respond to you ... desist from fighting against them. ... If they refuse to accept Islam, demand from them the jizya. If they agree to pay, accept it from them ... If they refuse to pay the tax, seek Allah's help and fight them. ${ }^{180}$

172 Lewis (n 78) 37-38; see generally, A Fattal, Le statut légal des non-musulmans en pays d'Islam, (Dar ElMachreq Books 1995). The millet system was abolished with the $19^{\text {th }}$-century Ottoman reforms granting equal legal standing to all subjects of the Empire. See R Şentürk, 'İslam'da Azınlık Hakları: Zimmiden Vatandaşa' (2006) (6) İslam Araştırmaları Merkezi 43, 50.

${ }^{173}$ In a verse it is ordained that Muslims avoid disputing with Scriptuaries. Q. 29:46; $c f$. Q. 33:40; Q. 2:127-130.

${ }^{174}$ B Lewis, The Middle East (Weidenfeld \& Nicolson 1995) 57.

${ }^{175}$ See M Khadduri, 'International Law' in: M Khadduri; HJ Liebesny, Law in the Middle East (Vol. I, Middle East Institute 1955) 349, 355.

176 See GF Nafziger; MW Walton, Islam at War: A History (Praeger 2003) 217.

177 Khadduri (n 20) 75.

${ }^{178}$ Sahih Muslim, Bk. 1:33.

${ }^{179}$ Haleem (n 44) 76-77.

${ }^{180}$ Sahih Muslim, Bk. 19:4294 
Beside this tradition, which recognises the prospect of tolerating pagans in return for the payment of the poll-tax, there are numerous verses evincing peace agreements signed between the Muslim and pagan forces. To illustrate, the following verse commands loyalty to treaties concluded with the pagans: 'How can there be a league ... with the pagans, except those with whom ye made a treaty ... as long as these stand true to you, stand ye true to them' (Q. 9:7). Another verse laments that Arab pagans broke their pledges when they had an edge over the Muslims: 'How (can there be such a league), seeing that if they get an advantage over you, they respect not in you the ties either of kinship or of covenant' (Q. 9:8). This verse also condemns those pagans who denounced their treaty obligations: '[T]hey respect not the ties either of kinship or of covenant. [T]hey have transgressed all bounds' (Q. 9:10). The cited verses evince that the supposed option of 'Islam or the sword' for the pagans does not always stand up to careful scrutiny. ${ }^{181}$ Be that as it may, once the Muslim polity had asserted itself over the Arabian Peninsula, it became almost impossible to come upon an openly pagan tribe in the region. Yet this had been a political outcome, rather than a doctrinal necessity of Islam.

Bearing such complexities in mind, it appears that the Muslim just war tradition has never taken an entirely pacifistic or defensive stance. Rather, all permissible modalities of jihad, as envisaged by binding sources and guiding State practice, have hitherto been employed in an effort to defend, consolidate or expand Islam. Islam, in this context, is characterised by its proselytising mission. Highlighting this rather assertive aspect of Islam, the great Muslim philosopher and historian Ibn Khaldun (d. 1406) maintained that major monotheistic traditions other than Islam did not impose a religious obligation of warfare except 'for purposes of defence:' 182

In the Muslim community, the holy war is a religious duty, because of the universalism of the Muslim mission and (the obligation to) convert everybody to Islam either by persuasion or by force [particularly in the case of pagans]. Therefore, caliphate and royal authority are united in Islam, so that the person in charge can devote the available strength to both of them at the same time. ${ }^{183}$

Although Khaldun had been woefully wrong in his assertion that 'other religious groups did not have a universal mission' to be carried out at the point of the sword, ${ }^{184}$ there was certainly merit in his point that Islam and the idea of 'pious striving' (peacefully or lethally) are interlaced with the ambition of spreading God's word. This notwithstanding, the defining characteristics to attain such religious objectives have been shown not to be clear-cut; in that the contours of jihad have

\footnotetext{
${ }^{181}$ Some pagan tribes, including the Banu Hamzah and Banu Kinana, had remained true to their treaty obligations. See Ali (n 45) 439.

${ }^{182}$ I Khaldun The Muqaddimah: An Introduction to History, F Rosenthal (trans.), (PUP 2005) 183.

183 Ibid.

${ }^{184}$ Ibid.
} 
historically been subject to change in harmony with the exigencies of circumstances. Thus, when the conditions so dictated, the sword has been put in the service of defending or promoting Islam. And when it was deemed expedient, military expeditions ceased in favour of peace treaties. Given the complex history and nonlinear evolution of jihad, it is nigh impossible to cogently construct a monolithic narrative of a wholly self-defensive or offensive jihad.

Monochromatic interpretive strategies often result in stale and disingenuous generalisations that overlook the broader rationale and concrete implications of pertinent verses, traditions and views on Muslim just war. While in the case of moderates, the objective in laying heavy emphasis over peaceable sources is benign (which is to restrict lethal force and promote spiritual values); in the case of radicals, the purported objective of ridding Muslims of all perceived injustices through a bellicose narrative fed by a select portion of sources divested of their context is unsettling. Unlike the moderates, radicals do not champion such progressive values as human rights, democratic governance, politico-religious tolerance, and peaceful co-existence of world religions. Besides, in the extremist spectrum, the end is thought to justify the means, no matter how sanguinary such means might be.

\section{Conclusion}

The question of legitimate force has lately caused much anguish to progressive Muslim scholars. When radical groups refer to jihad with a view to reviving 'the golden age of Islam,' alarm bells ring. Arousing such sentiments as resentment, rage and discontent, radicals regularly highlight the injustices (real or perceived) visited upon Muslims by corrupt Muslim governments and their 'pernicious imperial masters.' To them, all the problems of the Muslim world could be overcome if the false gods of materialism, modernisation, democracy and secularism are rejected outright. Propagating the idea that 'true' Islam is a panacea for socio-political ills, radical preachers draw a sharp, binary distinction between Islamic and un-Islamic systems, calling on Muslims to defend Islam by undertaking jihad in all its forms. In an effort to bolster their discourse, radicals make reference to a select class of verses, traditions and scholarly writings. Their reading of history is also highly selective; one which magnifies conflicts along religious lines, while minimising those aspects of the past unsuited their ideological mould. Worse still, radical thinking does not brook contingent knowledge, objective inquiry and reasonable compromise.

This article has argued that this biased intellectual stance largely divests Muslim just war of its theoretical and practical complexity. The article has further maintained that the moderate attempt to deconstruct this single-sided and combative portrayal of jihad has not been fully convincing. 
For the moderate reading of military jihad reduces legitimate Muslim warfare to the single cause of self-defence. Although this complies with the peremptory norms of modern international law, neither the textual material nor the historical practice duly supports such hermeneutics. Indeed, the afore-quoted sword verses, bellicose traditions, ${ }^{185}$ and innumerable military campaigns over the centuries resulting in the construction of many Muslim empires suggest that self-defence has never been the sole form of legitimate Muslim war. This does not, of course, gainsay the fact that Islam has also spread through peaceful means, such as verbal persuasion, trade or other forms of proselytising work. Nor does it question the fact that jihad comprehends the notions of peace, accommodation, and cooperation in inter-communal and international relations. The main point here is rather to stress that the trajectory of jihad has hitherto been dynamic, and hence non-linear and contextually contingent. In other words, the characteristics of striving (jihad) to attain Islamic objectives have historically been subject to intricate variations in line with the dictates of concrete circumstances. Since statecraft is not a detached, or abstract academic undertaking, Muslim just war has perforce been in touch with practical realities. It is hence evident that when the times so necessitated, the sword was in the defensive service of the Muslim realm. In like manner, when it was considered expedient, military expeditions were carried out, and/or treaties were concluded to advance the interests of Islam.

The tapestry of jihad, then, is variable, and more complex than suggested. Both dovish (however laudable their motives might be) and hawkish groups generally adopt a barren exegetical model that draws on isolated sources, while casting aside competing verses, traditions, doctrines and historical practice that might dictate more nuanced conclusions. Such interpretative efforts are in essence informed by literal textual exegeses, which disregard the complex history and nonlinear evolution of jihad. The way forward is not to construct a fictitious, monolithic metanarrative of a defensive or aggressive jihad, but to assess the source material within its contingent matrix by reference to the pertinent politico-historical context, connected verses and traditions, as well as the underlying logic and the overall spirit of Islam.

\footnotetext{
${ }^{185}$ Radicals, for instance, often refer to a tradition attributed to the Prophet: 'I have been ordered to fight with the people till they say, "none has the right to be worshipped but Allah"...' Hadith of Bukhari, Vol. IV, Hadith 4:196.
} 